\title{
Upregulation of Single Nucleotide Polymorphism of PD-1 Gene (rs10204525) in Chronic Hepatitis B Patients
}

\author{
Peyman Ghorbani ${ }^{1}$, Hamid Reza Mollaei ${ }^{1^{*}}$, Seyed Alimohammad Arabzadeh ${ }^{1}$ and \\ Mohammad Javad Zahedi
}

${ }^{1}$ Department of Medical Microbiology, Kerman University of Medical Sciences, Kerman, Iran

${ }^{2}$ Gastroenterology and Hepatology Research Center, Kerman University of Medical Sciences, Kerman, Iran

*Corresponding author: Hamid Reza Mollaei, PhD in Medical Virology, Assistant Professor in Medical Virology, Department of Medical Microbiology, Kerman University of Medical Sciences, Kerman, Iran, Tel: +98-9133974926

\begin{abstract}
Background: Programmed death-1 (PD-1) is major inhibitory molecule that reduces $T$ cell activation. PD-1 and their polymorphisms have separately been shown to be associated with hepatitis B virus (HBV) infection. Therefore, we aimed to investigate the association of PD1 polymorphisms with potential of chronic hepatitis B infection in Iranian population to do a Case-Control study.

Methods: In this study HBV DNA, and PD-1 mRNA, were extracted from 60 patients with chronic hepatitis $B$ and 60 healthy blood donors as control. HBV Viral Load, polymorphism genotype of the two groups and level expression of PD1 gene were evaluated using Real time PCR method.

Results: Age mean of the control group was $40.7 \pm 3.7$ and $35.86 \pm 11.18$ year's old age for the case group. The GG allele between the two groups had the same frequency (73.3\% in CHB group and $80 \%$ in healthy group). The GA allele in patients with hepatitis B $(20 \%)$ was most frequent. There was a significant association between the GA allele and chronic hepatitis B infection. There was no significant relationship between the ages of the subjects with SNPrs10204525. Also, the expression of PD-1 mRNA was higher in people with hepatitis $B$ than in healthy group.

Conclusion: The results of this study showed that there is a significant relationship between the presence of rs10204525 polymorphisms in the PD-1 gene in patients with chronic hepatitis $B$ infection and the association between the GA allele and chronic hepatitis B can be linked.
\end{abstract}

\section{Keywords}

Chronic hepatitis B, Single nucleotide polymorphism, rs10204525, Programmed cell death-1

\section{Introduction}

The viral infections cause many deaths in many parts of the world. Hepatitis B virus (HBV) infection is also one of those viral diseases and a major public health problem [1]. HBV can cause a variety of diseases in humans from inactive carriers to progressive liver disease, including chronic hepatitis $B$, cirrhosis and hepatocellular carcinoma (HCC) [2]. More than 350 million people in the world are chronic hepatitis $B$ which is caused by infection with the hepatitis $B$ virus. Most people infected with hepatitis $B$ virus are able to remove the virus but in 5 to 10 percent of the population, the disease progresses to chronic disease [3]. Chronic hepatitis $B$ infection refers to an inflammation of the liver that lasts at least 6 months, and the person infected with hepatitis B virus and $\mathrm{HBs} A g$ remains positive up to 6 months post-infection [4]. The immune system is main cause of chronic hepatitis. An individual's immune system clears the HBV virus during an acute infection and, as a result, improves the disease when fully functioning correctly, so in an immune defect, acute infection becomes a chronic infection [5]. Several studies have shown that the host genetic context, including the diversity of genes involved in the immune system and cytokines, and single nucleotide polymorphisms, have a significant role in determining the immunogenicity and clinical course of the hepatitis B virus infection [6]. Cytotoxic T-lymphocytes (CTLs) play a major role in the fight against acute hepatitis $B$ infection and remove of 
viral infection from hepatocytes. However, if the virus does not get properly cleaned out of the body, the hepatitis $B$ virus remains, and a dynamic balance between virus replication in hepatocytes and the host's immune response is established and, in the long run, causes the progress of the disease [7]. In fact, in patients with chronic hepatitis $B$ infection, viral T-specific cells did not have high activity, which would result in the production and secretion of adequate antiviral cytokines, inappropriate functioning of cytotoxic $T$ lymphocytes, and thus the persistence of the virus in the body [8]. The Programmed cell death-1 (PD-1, CD 279) is a 55-KD protein and a type of the immunoglobulin super family and is an immunological receptor belonging to the CD28/CTLA4 family and is known to be an inhibitor of receptor $[7,9]$. PD-1 presented at the level of activated T cells, B lymphocytes, natural killer cells and myeloid dendritic cells, and can be seen to a high degree level at $T$ lymphocytes that enters to the resting stage $[10,11]$. The inhibitory signals provided by PD-1 and its ligands, PD-L1 and PD-L2 both of which are located in 9p24 chromosome location, are necessary to maintain the balance of T-cell activation, tolerance and immune-mediated tissue damage, and inhibition of its function can result in $T$ cells returning and their effective re-activity [12-14]. The PD-1 gene is located on chromosome number 2 in the q37.3 region, and more than 30 single nucleotide polymorphism sites (SNPs) are in different regions of the gene include promoter, intron, exon, and 3'UTR region [15-17]. Studies have shown that there is a link between these SNPs and various diseases. In recent studies, an SNP in the 3' UTR region of PD-1 gene, rs10204525 has been shown to be associated with the pathogenesis of chronic hepatitis $B$ infection $[11,18,19]$. However, there is still not much information about this SNP and its association with chronic hepatitis $B$, but it seems the importance of PD-1 in regulating activity of $T$ cells and its role in the development of chronic viral infections; Accordingly, we design a case control study for evaluation the level of PD-1 mRNA expression in peripheral blood nuclear cells and its relation with clinical parameters and correlation between polymorphism of PD-1 (rs10204525) and susceptibility of chronic hepati- tis in patients with HBV infection in Kerman province, southeast of Iran.

\section{Materials and Methods}

\section{Patients}

In a case control study 60 blood sample were collected from patients with chronic Hepatitis B virus infection and 60 samples were collected from healthy blood donors as control group during July 2016 to October 2017. Mean years old age of case group was $40.7 \pm 3.7$, and for control group was $35.86 \pm 11.18$ years.

\section{Real time PCR for HBV load}

About five $\mathrm{ml}$ of peripheral blood were collected from each patient into EDTA-containing vacutainer tubes. Plasma was separated and stored at $-70{ }^{\circ} \mathrm{C}$. HBV DNA was extracted from $200 \mu \mathrm{L}$ of plasma with High Pure Viral Nucleic Acid kit (Roche Diagnostics, Germany). Extracted DNA pellets were resuspended in $100 \mu \mathrm{L}$ of prewarmed Elution buffer and stored at $-20{ }^{\circ} \mathrm{C}$ until use. For Quantification of HBV DNA we use Real Time HBV kit (artus HBV kit, Qiagen, Germany). Quantitative determination of the amplified products was done with the Rotor Gene Q (Qiagen, Germany).

\section{Detection of rs10204525}

Detection of rs10204525 was done using Real Time TaqMan probe assay with specific primers and probes from position 251 of the mRNA PD-1 gene (NM_005018) that designed by Beacon designer software (Primer Biosoft, USA). Sequences of primers and probes were shown in Table 1. Primers and probes synthesized by Metabion Company (Metabion international AG, Germany). For Real Time PCR and detection polymorphisms of rs10204525, Five $\mu$ l of DNA sample that was extracted from samples, combined with $15 \mu \mathrm{l}$ reaction mixture of TaqMan Master Mix (Thermo fisher Scientific, USA) contain $10 \mathrm{pmol}$ of each primer and five pmol of probes. The condition for the TaqMan assay was initially $10 \mathrm{~min}$ with hot start Taq DNA polymerase at $95^{\circ} \mathrm{C}$ followed by 40 cycles at $95{ }^{\circ} \mathrm{C}$ for $5 \mathrm{sec}$ and $60^{\circ} \mathrm{C}$ for $40 \mathrm{sec}$. In each cycle at the extension step, the fluorescent Probe

Table 1: Primer and probe sequences for detection of SNP and PD-1 gene expression.

\begin{tabular}{|c|c|c|}
\hline Name & Position & Sequence \\
\hline Pd1 -F & $463-477$ & TTGGGAGGGCAGAAGa \\
\hline Pd1-R & $630-647$ & GGATGTGAGGAGTGGATA ${ }^{a}$ \\
\hline Probe-A & $495-511$ & FAM- CCCCATATGCCCACCCT -BHQ1 \\
\hline Probe-G & $495-511$ & JOE- CCCCATGTGCCCACCCT-BHQ1 ${ }^{\mathrm{b}}$ \\
\hline GAPDH-F & 294-314 & CTCTGGTAAAGTGGATATTGT \\
\hline GAPDH-R & $359-378$ & GGTGGAATCATATTGGAACA \\
\hline PD-1 F & $1484-1503$ & TAGAGAAGTTTCAGGGAAGGc \\
\hline PD-1 R & $1543-1560$ & ATGTGTAAAGGTGGAGGGc \\
\hline
\end{tabular}

a) Primer sequence for determination SNP polymorphism using TaqMan; b) Specific probes for determination SNP polymorphism using TaqMan; c) Primer sequences for relative gene expression of PD-1. 
signals of rs10204525 were measured, at Green channel for $G$ allele (FAM), Yellow channel for A allele (JOE). Quantitative determination of the amplified products was done with the Rotor Gene Qthermo cycler (Qiagen, Inc).

\section{RNA extraction and CDNA synthesis}

RNA was extracted from a $100 \mu$ l volume of serum sample using precipitation method (RIBO-prep, ILS). Briefly, specimen was added to a tube containing $300 \mu \mathrm{l}$ of lysis buffer and $400 \mu \mathrm{l}$ of precipitate buffer, mixed, and incubated for $10 \mathrm{~min}$ at room temperature; and centrifuge in $13000 \mathrm{rpm}$ for three minutes. Then washed once with $500 \mu \mathrm{l}$ of wash buffer W3, once with $200 \mu \mathrm{l}$ of $70 \%$ (V/V) ethanol (Wash buffer W4), and then dried at $60^{\circ} \mathrm{C}$ for $10 \mathrm{~min}$. It was then resuspended in 50 $\mu \mathrm{l}$ of RNase-free water and converted into CDNA by RTPCR. For RT $5 \mu$ l of RNA was added to a reaction mixture $(15 \mu \mathrm{l})$ containing $20 \mathrm{mM}$ Tris- $\mathrm{Hcl}(\mathrm{pH} 8.4), 50 \mathrm{mM} \mathrm{KCl}$, $7.5 \mathrm{mM} \mathrm{MgCl}_{2}$, each deoxynucleoside triphosphate at a concentration of $1.5 \mathrm{mM}, 25 \mathrm{ng}$ of each random primer [(pdN)6;, $1.6 \mathrm{U}$ of RNasin, and $200 \mathrm{U}$ of Moloney murine leukemia virus reverse transcriptase (Thermofisher, Germany). The reaction mixture was incubated at room temperature for $10 \mathrm{~min}, 37^{\circ} \mathrm{C}$ for $45 \mathrm{~min}$, and $95^{\circ} \mathrm{C}$ for $5 \mathrm{~min}$ and quenched on ice.

\section{mRNA PD1 gene expression}

For determination expression level of PD1 gene, after Synthesis of cDNA, add five microliters of CDNA in duplicate into the optical $0.1 \mu \mathrm{L}$ microtube. The Maxima SYBR Green Master mix (Thermo fisher) were used base on instruction kit. After alignment of these regions between all of them in EBML-EBI, Real time PCR primers were design for target mRNA gene (NCBI Reference
Sequence: NM_005018.2), also; GAPDH gene were used for internal control. All of sequences of primers were purchased from Metabion Company (Metabion international AG, Germany) (Table 1). Real-time PCR was carried out on an Rotor GeneQ Qthermo cycler (Qiagen, Inc.) using the following conditions: $95^{\circ} \mathrm{C}$ for $10 \mathrm{~min}$, followed by 35 cycles of $95^{\circ} \mathrm{C}$ for $15 \mathrm{sec}$ and 60 ${ }^{\circ} \mathrm{C}$ for $30 \mathrm{sec}$. Raw data can then be analyzed with REST Relative Quantification Software version 2.2.3 (Qiagen, Inc.), generally using the automatic cycle threshold (Ct) setting for assigning baseline and threshold for $\mathrm{Ct}$ determination. Delta $\mathrm{Ct}$ values were used for the analysis. Relative expression (RE) of the sample gene was calculated using the $\Delta \Delta C T$ method and, also we used GAPDH for internal control or housekeeping gene.

\section{Biochemical and serological tests}

The serum blood from the patients with chronic hepatitis B was assayed for Serum Glutamic-Oxaloacetic Transaminase (SGOT), Serum Glutamate-Pyruvate Transaminase (SGPT) and alkaline phosphatase (ALK) at our clinical laboratory using an automated analyzer ( $\mathrm{Hi}-$ tachi, Cobaas). HBsAg and $\mathrm{HBeAg}$ as well as Anti-HCV, Anti-HIV and Hepatitis D antigen were determined using commercial Enzyme-linked Immunosorbent Assay (ELISA) technique kits (Diapro, Italy).

\section{Results}

Out of 60 samples of case group were $43(71.6 \%)$ Males and $17(28.4 \%)$ females and in control group were 56(93.3\%) Males and 4(6.7\%) females. In Table 2, the relationship between SNPrs10204525 and the gender of people in different groups has been investigated. Regarding the results, there was no significant relation between sex and SNP rs 10204525. Polymorphism of the

Table 2: Frequency of SNP alleles in Male and Female at different groups.

\begin{tabular}{|c|c|c|c|c|c|c|c|}
\hline \multirow[t]{2}{*}{$\begin{array}{l}\text { Groups } \\
\text { Sex }\end{array}$} & \multicolumn{4}{|c|}{ SNP Genotype } & & \multirow[t]{2}{*}{$\mathrm{Df}^{*}$} & \multirow[t]{2}{*}{ P.value } \\
\hline & AA & GA & GG & GG & Total & & \\
\hline \multirow[b]{2}{*}{ Healthy } & Male & $12(12.85 \%)$ & 0 & $44(80.45 \%)$ & $56(93.3 \%)$ & \multirow[t]{2}{*}{1} & \multirow[t]{2}{*}{$0.399^{* *}$} \\
\hline & Female & 0 & 0 & $4(6.7 \%)$ & $4(6.7 \%)$ & & \\
\hline \multirow[t]{2}{*}{$\mathrm{CHB}^{1}$} & Male & $3(4.18 \%)$ & $11(15.34 \%)$ & $29(40.46 \%)$ & $43(71.6 \%)$ & \multirow[t]{2}{*}{2} & \multirow[t]{2}{*}{0.212} \\
\hline & Female & $1(3.52 \%)$ & $1(3.52 \%)$ & $15(52.9 \%)$ & $17(28.4 \%)$ & & \\
\hline
\end{tabular}

"df: Degree of freedom; "*no Significant statistical difference, 1: Chronic Hepatitis B.

Table 3: Frequency of SNP alleles in different groups.

\begin{tabular}{|c|c|c|c|c|c|c|}
\hline \multirow[t]{2}{*}{ Groups } & & \multicolumn{3}{|c|}{ Polymorphism } & $\mathbf{d f}^{*}$ & P.value \\
\hline & & AA & GA & GG & \multirow{5}{*}{2} & \multirow{5}{*}{$0.0001^{* *}$} \\
\hline \multirow[t]{2}{*}{ Healthy } & Frequency & 12 & 0 & 48 & & \\
\hline & Percent & $20 \%$ & $0 \%$ & $80 \%$ & & \\
\hline \multirow[t]{2}{*}{ Chronic hepatitis B } & Frequency & 4 & 12 & 44 & & \\
\hline & Percent & $6.7 \%$ & $20 \%$ & $73.3 \%$ & & \\
\hline
\end{tabular}

"df: Degree of freedom; ${ }^{*}$ Significant statistical difference. 
rs10204525 has a significant difference in hepatitis B and healthy subjects (P.Value $<0.001$ ). So percent and prevalence of GG allele is equal in healthy and chronic hepatitis $B$ patient groups, but frequency of AA allele in healthy people and GA allele in chronic hepatitis B patient group were more than other groups. In other words, there is a significant relation between the GA allele and the hepatitis $B$ infection (Table 3 ). The relative mRNA expression of PD-1 in patients with chronic hepatitis $\mathrm{B}, \mathrm{HBeAg}$ positive, $\mathrm{HBe} \mathrm{Ag}$ negative and healthy group was shown in Figure 1. The expression level of mRNA PD-1 in HBeAg positive patients is higher than $\mathrm{HBe} \mathrm{Ag}$ negative and in patients with chronic hepatitis $\mathrm{B}$, is more than, $\mathrm{HBe} \mathrm{Ag}$ negative group. All of 120 samples in this study (case, control), 8 samples had HBeAg positive and 112 samples were $\mathrm{HBe} \mathrm{Ag}$ negative. There was no significant relation between $\mathrm{HBe} A g$ and SNP alleles of PD-1, ( $P>0.33$ ) (Figure 2). SNP alleles of rs10204525 have been evaluated in chronic hepatitis $B$ with HBV DNA load. According to the results, there is a significant relationship between rs10204525 polymorphism with $\mathrm{HBe} \mathrm{Ag}(\mathrm{P}<0.05)$. So that in $\mathrm{HBe} \mathrm{Ag}$ positive patients, the $G G$ allele was more than other alleles and the $A A$ allele were least of alleles. Regarding the results, the female or male status of the subjects in the study groups is not related to SNPrs10204525 (Table 3). The levels of Serum Glutamic-Oxaloacetic Transaminase (SGOT), Serum Glutamate-Pyruvate Transaminase (SGPT) and alkaline

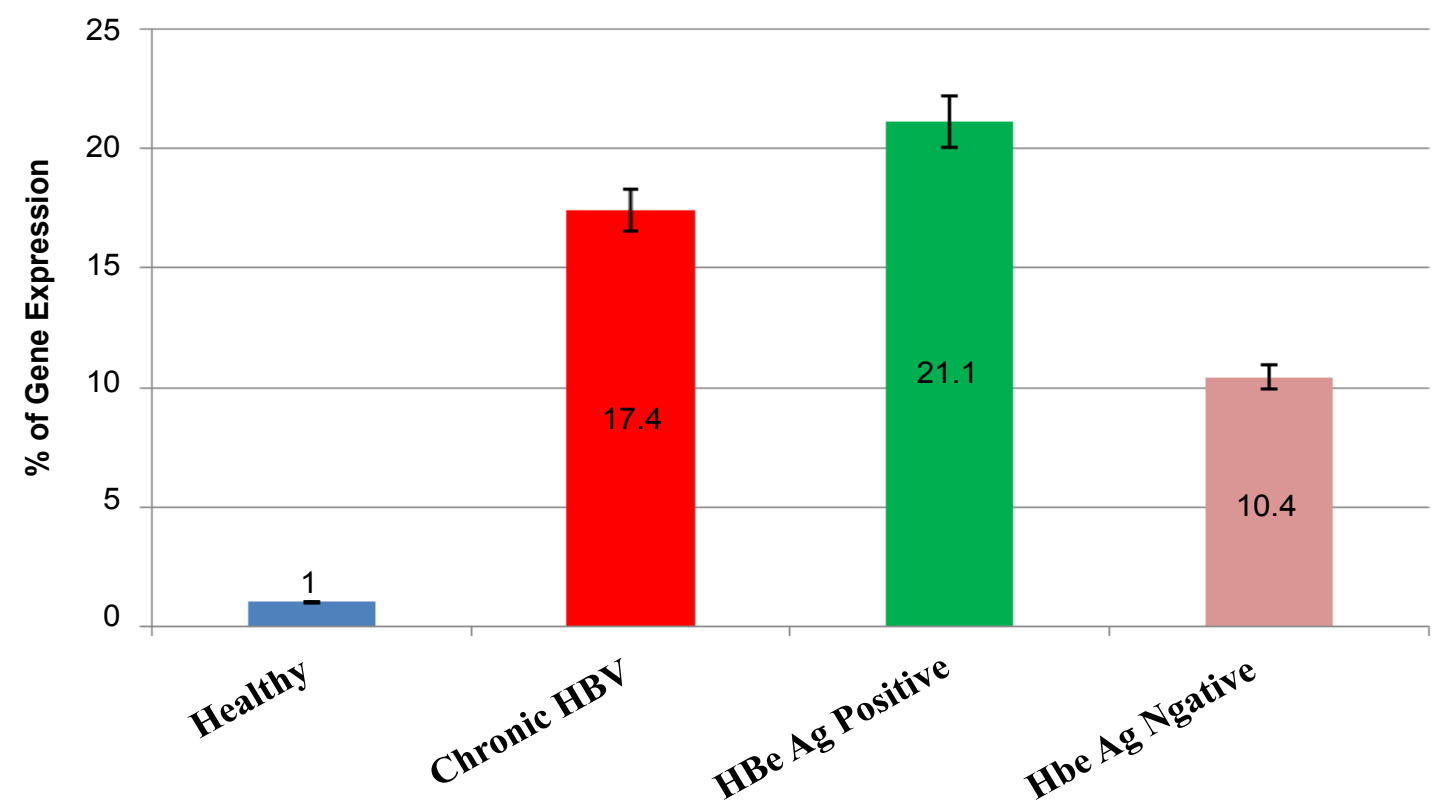

Figure 1: Relative gene expression of PD1 mRNA in three groups of Patients.

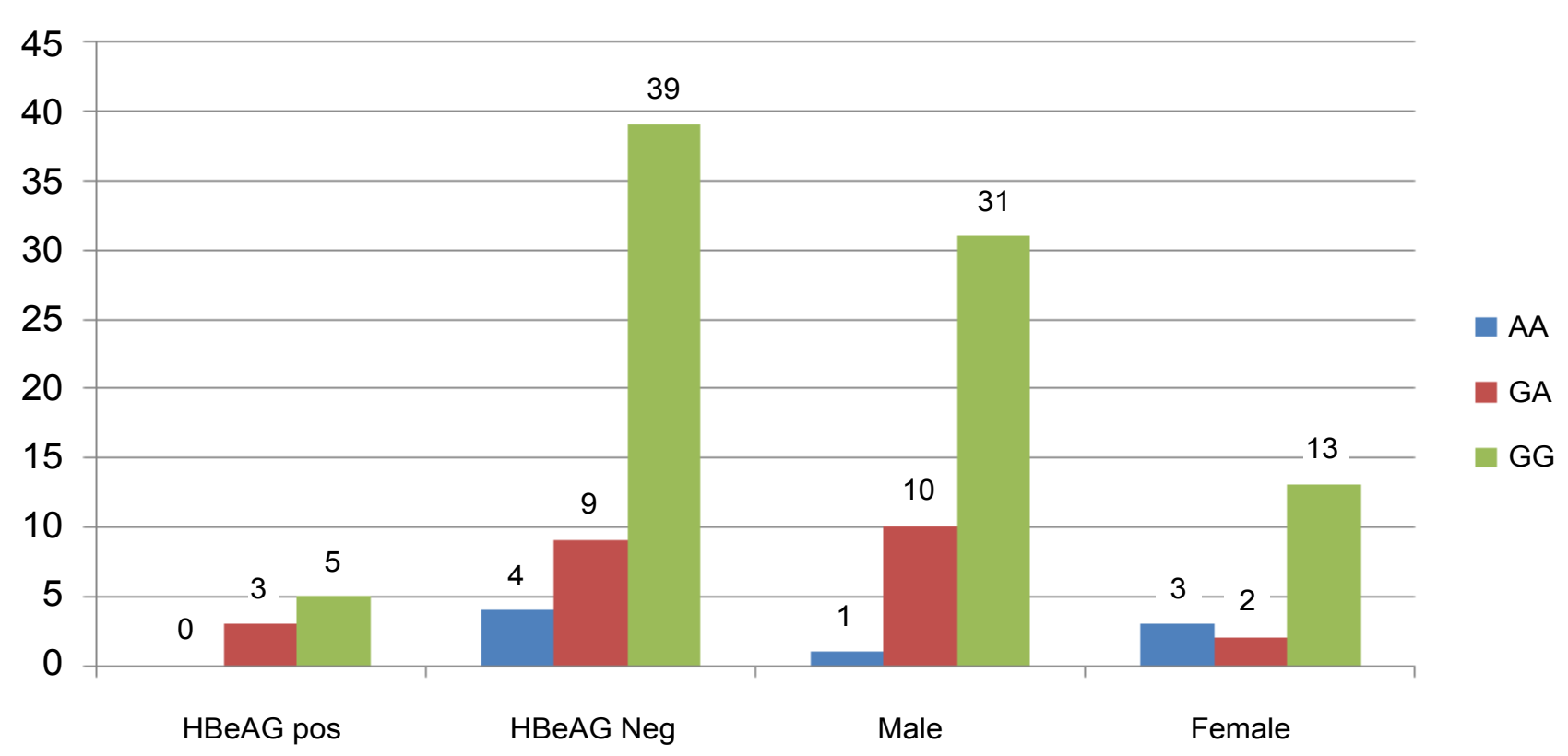

Figure 2: Frequency distribution genotype of rs10202545 in two groups $\mathrm{HBe} \mathrm{Ag}$ positive and negative and different gender. 
Table 4: Frequency of SNP alleles in different HBV Load levels.

\begin{tabular}{|c|c|c|c|c|c|}
\hline \multicolumn{2}{|c|}{ HBV Load Range (Copies/ml) } & \multicolumn{3}{|c|}{ SNP Alleles } & \multirow{3}{*}{\begin{tabular}{|l|} 
Total \\
5 \\
\end{tabular}} \\
\hline & & \multirow{2}{*}{$\begin{array}{l}\text { AA } \\
0^{\mathrm{a}}\end{array}$} & \multirow{2}{*}{\begin{tabular}{|l|} 
GA \\
$2^{\mathrm{a}}$
\end{tabular}} & \multirow{2}{*}{$\begin{array}{l}\text { GG } \\
3^{a}\end{array}$} & \\
\hline $10^{5}-10^{6}$ & Count & & & & \\
\hline \multirow[t]{3}{*}{ (copies/ml) } & $\%$ within HBV Load & $0.0 \%$ & $40.0 \%$ & $60.0 \%$ & $100.0 \%$ \\
\hline & \% within SNP & $0.0 \%$ & $16.7 \%$ & $6.8 \%$ & $8.3 \%$ \\
\hline & $\%$ of Total & $0.0 \%$ & $3.3 \%$ & $5.0 \%$ & $8.3 \%$ \\
\hline \multirow{4}{*}{$\begin{array}{l}10^{6}-10^{7} \\
\text { (copies/ml) }\end{array}$} & Count & $0^{a}$ & $2^{a}$ & $8^{\mathrm{a}}$ & 10 \\
\hline & \% within HBV Load & $0.0 \%$ & $20.0 \%$ & $80.0 \%$ & $100.0 \%$ \\
\hline & \% within SNP & $0.0 \%$ & $16.7 \%$ & $18.2 \%$ & $16.7 \%$ \\
\hline & $\%$ of Total & $0.0 \%$ & $3.3 \%$ & $13.3 \%$ & $16.7 \%$ \\
\hline \multirow{4}{*}{$\begin{array}{l}10^{7}-10^{8} \\
\text { (copies/ml) }\end{array}$} & Count & $1^{a}$ & $0^{\mathrm{a}}$ & $3^{a}$ & 4 \\
\hline & $\%$ within HBV Load & $25.0 \%$ & $0.0 \%$ & $75.0 \%$ & $100.0 \%$ \\
\hline & $\%$ within SNP & $25.0 \%$ & $0.0 \%$ & $6.8 \%$ & $6.7 \%$ \\
\hline & $\%$ of Total & $1.7 \%$ & $0.0 \%$ & $5.0 \%$ & $6.7 \%$ \\
\hline \multirow{4}{*}{$\begin{array}{l}10^{8}-10^{9} \\
\text { (copies/ml) }\end{array}$} & Count & $0^{\mathrm{a}}$ & $3^{a}$ & $7^{a}$ & 10 \\
\hline & $\%$ within HBV Load & $0.0 \%$ & $30.0 \%$ & $70.0 \%$ & $100.0 \%$ \\
\hline & \% within SNP & $0.0 \%$ & $25.0 \%$ & $15.9 \%$ & $16.7 \%$ \\
\hline & $\%$ of Total & $0.0 \%$ & $5.0 \%$ & $11.7 \%$ & $16.7 \%$ \\
\hline \multirow{4}{*}{$\begin{array}{l}>10^{9} \\
\text { (copies/ml) }\end{array}$} & Count & $3^{a}$ & $5^{a}$ & $23^{a}$ & 31 \\
\hline & $\%$ within HBV Load & $9.7 \%$ & $16.1 \%$ & $74.2 \%$ & $100.0 \%$ \\
\hline & $\%$ within SNP & $75.0 \%$ & $41.7 \%$ & $52.3 \%$ & $51.7 \%$ \\
\hline & $\%$ of Total & $5.0 \%$ & $8.3 \%$ & $38.3 \%$ & $51.7 \%$ \\
\hline \multirow[t]{4}{*}{ Total } & Count & 4 & 12 & 44 & 60 \\
\hline & $\%$ within HBV Load & $6.7 \%$ & $20.0 \%$ & $73.3 \%$ & $100.0 \%$ \\
\hline & $\%$ within SNP & $100.0 \%$ & $100.0 \%$ & $100.0 \%$ & $100.0 \%$ \\
\hline & $\%$ of Total & $6.7 \%$ & $20.0 \%$ & $73.3 \%$ & $100.0 \%$ \\
\hline
\end{tabular}

a) Each subscript letter denotes a subset of SNP categories whose column proportions do not differ significantly from each other at the 0.05 level.

phosphatase (Alk) were measured. The results showed that mean of SGOT was $39.20 \pm 3.96 \mathrm{lU} / \mathrm{ml}$, Alk value of $107.63 \pm 10.01$ and SGPT was $40.98 \pm 4.91$. There was a significant relation between SGOT, SGPT and GG allele but no about Alk (Data not shown). Investigating the relationship between SNPrs10204525 and chronic hepatitis $B$ with HBV DNA in different groups showed a significant relationship between SNPrs10204525 and HBV DNA load in hepatitis $B$ virus $(P<0.05)$ (Table 4). In patients with chronic hepatitis $B$, the rate of the $G G$ allele is more than other salleles.

\section{Discussion}

Hepatitis $B$ virus (HBV) is one of the main causes of chronic liver infection. According to the WHO estimates, around 350 to 400 million people worldwide are infected with the Hepatitis B virus and each year about 500,000 to $1,200,000$ die due to hepatitis $B$ complications $[20,21]$. In Iran, it has been estimated that 1.5 million people have been diagnosed with hepatitis $B$, of which 15 to 45 percent are susceptive to cirrhosis and liver cancer [22]. Chronic hepatitis B (CHB) infection refers to a past inflammation of the liver at least six months and the person infected with $\mathrm{HBV}, \mathrm{HBs}$ Ag remains positive for up to six months after infection [23]. Chronic hepatitis $B$ remains for many years, even for decades. In many people, the disease is quite mild and does not cause any particular liver damage. However, in some patients, inflammation continues and causes the destruction of liver cells, which eventually becomes cirrhosis and liver cancer [24]. The main cause of the progression of hepatitis is chronic hepatitis, a person's immune system. In the event of a complete and correct immune response during an acute infection, it clears the HBV virus and, treatment. However, in the case of a defective immune system, acute infection will become a chronic infection [25]. PD-1 (CD279) is a receptor of the CD28/CTLA-4 family. The inhibitory signals provided by the PD-1 linkage and its ligands, PD-L1 (B7-H1; CD274) and PD-L2 (B7-DC, $\mathrm{CD} 273$ ), are provided to maintain the required balance for T-cell activation, Tolerance, and immune-mediated tissue damage, and inhibition of its function can reverse the function of T cells and their effective re-activity [2628]. There are several studies that points to the role of PD-1/PD-L in preventing autoimmune disorders. It has been shown that the modified PD-1 function and its li- 
gands are associated with several autoimmune diseases in humans [29-31]. Studies have shown that the frequencies of PD-1 genes and alleles in individuals with clinical symptoms of chronic hepatitis B are different from healthy subjects, and rs10204525 polymorphism play a predisposing role in the disease and severity [32]. Regarding the role of PD-1 in the chronic infection of hepatitis $B$ in several studies, their association with the progression of infection, and SNP rs10204525 in the expression of PD-1 affects chronic hepatitis B infection is still not completely determined [33]. So, in this study, measured the level of PD-1 mRNA expression in PBMCs (Peripheral Blood Mononuclear Cells) and its association with the clinical parameters of hepatitis $B$ infection and genotypes of the PD-1 rs10204525 polymorphism, which include three genotypes $A A, G A$ and $G G$. In this study showed that in patients with chronic infectious HBV expression of PD-1 mRNA significantly increased incompared with healthy group. Increased expression level of the PD-1 mRNA was associated with increased levels of HBV DNA load and positive $\mathrm{HBe} \mathrm{Ag}$ inserum. On the other hand, the viral load and $\mathrm{HBe} A g$ represent the replication of the virus; therefore, these findings indicate that PD1 gene expression can play a role in the development of chronic infections [34]. Also, in this study, the levels of liver functional enzymes were tested, results have shown that SGOT, SGPT and ALK enzymes, were significantly related to the PD-1 mRNA expression $(P<0.001)$. As each increases of these enzymes, the expression of PD-1 mRNA also increases. In another part of the study, the relationship between SNPrs10204525 alleles with the level of liver enzymes was determined in patients with chronic hepatitis B and it was showed that the levels of all enzymes were significantly associated with GG allele of SNPrs10204525. In patients with chronic HBV infection, which have severe viremia and $T$ cell dysfunction, PD-1 have a role in regulating of $T$ cells [34,35]. PD-1 expression has a direct relation in $T$ cells $\mathrm{CD}^{+}$and $\mathrm{CD}^{+}$with HBV DNA levels and an inverse relationship with $T$ cells activated. In addition, HBV DNA levels and $\mathrm{HBeAg}$ indicate the high expression of PD-1 in chronic HBV infection [28,36]. Our research showed that the level of PD-1 expression in PBM cells was related to $\mathrm{HBV}$ DNA levels and $\mathrm{HBeAg}$, which confirmed these findings and important role of the PD-1 in the HBV virus replication pathway, by suppressing host immune responses $[37,38]$. In previous studies, Zhou, et al. [32]. Have shown a close correlation between increased expression of PD-1 and high levels of HBV replication [32]. In a study showed that the level of PD-1 mRNA expression in patients with chronic hepatitis $B$ was higher than the control group, there is no association between levels of PD-1 mRNA expression in peripheral blood nucleus and SGPT, SGOT, ALK in patients with chronic HBV infection [34]. Frequency of rs10204525 alleles in different geographic region of world is variable, in a study by Zhang, et al. [11]; the $A A$ allele was the most frequent in $C H B$ patients in China, but in a study by Hou and colleagues in other region of China, Showed that the GG allele is equal in healthy subjects and people with hepatitis $B$, but the AA allele in the healthy subjects and GA was highest in people with hepatitis $B$ infection, However in our study frequency of $\mathrm{GG}$ allele in $\mathrm{CHB}$ group was higher than the control group, and this genotype was associated with a significant increase in the level of PD-1 mRNA, the difference between frequency of genotypes of rs 10202545 can be due to racial and ethnic differences of individuals $[11,39]$. In our research and previous studies, there was a close relationship between increased expression of PD-1 and increased levels of HBV viral transcription. In addition, active viral transcription of HBV leading to disease progression in patients with chronic infections of HBV and increased expression of PD-1 on HBV specific $\mathrm{T}$ cells $\mathrm{CD}^{+}, \mathrm{CD}^{+}$and $\mathrm{T}$ regulatory cells $\mathrm{CD} 25$, Causing a defect in the function of $T$ cell response and continued $\mathrm{HBV}$ infection. Therefore, the negative effect of GA genotype on PD1 rs10204525 on chronic HBV infection and progression of the disease may be expressed, at least, through its association with the increase of PD-1 expression [40]. Association between a specific PD1 polymorphism and an increase in PD-1 expression, as well as clinical and viral symptoms, suggests that this polymorphism may potentially be used as a genetic marker to monitor the prognosis of chronic HBV infection. In addition, it has been shown that T-cell antiviral responses to chronic hepatitis $B$ can be restored and improved by PD-1 pathway obstruction [40]. Therefore, this polymorphism may be a potential target for the design of immunotherapy interventions and the screening and selection of patients with HBV with a specific genetic immunological profile and will be effective in future approaches to immunotherapy for hepatitis $B$ virus disease [41]. Further studies are definitely necessary to confirm the direct functional association between this polymorphism and the PD-1 molecule. Moreover, given that the findings of this study were only obtained from people of Kerman province, reproductive studies are required in different ethnic groups.

\section{Conclusion}

In conclusion, this study showed that in patients with chronic HBV infection serum PD-1 mRNA levels significantly increased associated with liver enzymes (SGPT, SGOT) and HBV viral replication (HBV DNA Load), increase expression of PD-1mRNA can effect on process of chronic infection of hepatitis $B$ by facilitating the transcription of the HBV virus by an anti-cancer viral immune response, and this can be at least partially related to SNPrs10204525 in PD1 3' UTR. These data may provide immune histochemistry data to monitor the prognosis of diseases and design an approach to immunotherapy for HBV-related diseases. At the end, it is suggested that more attention be paid to other PD1 polymorphisms and their association with cases such as liver cancer in patients with hepatitis. 


\section{Conflicts of Interest}

We declare that we have no conflict of interest.

\section{Acknowledgement}

This study was performed as an MSc thesis of Peyman Ghorbani, and it was financially supported by the GI-Liver Research center, Kerman University of Medical Sciences, Kerman, Iran and Department of medical microbiology, Laboratory of medical virology in Kerman, Iran.

\section{Sources of Support}

This study was performed as an MSc thesis of Peyman Ghorbani, and it was financially supported by the GI-Liver Research center, Kerman University of Medical Sciences, Kerman, Iran and Department of medical microbiology, Laboratory of medical virology in Kerman, Iran.

\section{References}

1. Afshar RM, HR Mollaie (2012b) Use of ALLGIO probe assays for detection of HBV resistance to adefovir in patients with chronic hepatitis B, Kerman, Iran. Asian Pac J Cancer Prev 13: 5463-5467.

2. Afshar RM, HR Mollaie (2012a) Detection of HBV resistance to lamivudine in patients with chronic hepatitis B using Zip nucleic acid probes in Kerman, southeast of Iran. Asian Pac J Cancer Prev 13: 3657-3661.

3. Monavari SH, H Keyvani, H Mollaie, RV Roudsari (2013) Detection of rtN236T mutation associated with adefovir dipivoxil resistance in Hepatitis $B$ infected patients with YMDD mutations in Tehran. Iran J Microbiol 5: 76-80.

4. Motahar Minoo, Seyed AliMohammad Arabzadeh, Hamidreza Mollaei, Zahra Iranmanesh, Najmeh Nikpour, et al. (2016) Evaluation of HBV resistance to tenofovir in patients with chronic hepatitis B using ZNA probe assay in Kerman, southeast of Iran. Asian Pacific Journal of Tropical Disease 6: 513-516.

5. Soleimani Fariba, Seyed Ali Mohammad Arabzadeh, Hamidreza Mollaei, Zahra Iranmanesh, Najmeh Nikpour, et al. (2016) Evaluation of the frequency of precore/core mutation in patients with chronic hepatitis B, Kerman, Southeast of Iran. Asian Pacific Journal of Tropical Disease 6: 603-607.

6. Iranmanesh Z, HR Mollaie, SA Arabzadeh, MJ Zahedi, M Fazlalipour, et al. (2015) Evaluation of the frequency of the IL-28 polymorphism (rs8099917) in patients with chronic hepatitis C using Zip nucleic acid probes, Kerman, Southeast of Iran. Asian Pac J Cancer Prev 16: 1919-1924.

7. Xibing GY, Xiaojuan, W Juanhua (2013) PD-1 expression on CTL may be related to more severe liver damage in CHB patients with $\mathrm{HBV}$ genotype $C$ than in those with genotype B infection. J Viral Hepat 20: e1-e2.

8. Tang ZS, YH Hao, EJ Zhang, CL Xu, Y Zhou, et al. (2016) CD28 family of receptors on T cells in chronic HBV infection: Expression characteristics, clinical significance and correlations with PD-1 blockade. Mol Med Rep 14 1107-1116.

9. Teng XY, Wang P, Zhou XG, Shen B, Sun L, et al. (2011) PD-1/ PD-L1 expressions in liver tissues of patients with chronic HBV infection. Zhonghua Gan Zang Bing Za Zhi 19: 345-348.
10. Yazdanpanah SB, Geramizadeh S, Nikeghbalian SA, Malek-Hosseini (2016) Hepatocellular carcinoma and its precursors in 103 hbv-related cirrhotic explanted livers: A study from south iran. Hepat Mon 16: e38584.

11. Zhang G, N Li, P Zhang, F Li, C Yang, et al. (2014) PD-1 mRNA expression is associated with clinical and viral profile and PD1 3'-untranslated region polymorphism in patients with chronic HBV infection. Immunol Lett 162: 212-216.

12. Peng G, S Li, W Wu, X Tan, Y Chen, et al. (2008) PD-1 upregulation is associated with HBV-specific $T$ cell dysfunction in chronic hepatitis B patients. Mol Immunol 45: 963-970.

13. Xie Z, Y Chen, S Zhao, Z Yang, $X$ Yao, et al. (2009) Intrahepatic PD-1/PD-L1 up-regulation closely correlates with inflammation and virus replication in patients with chronic HBV infection. Immunol Invest 38: 624-638.

14. Yahyapour Y, M Karimi, HR Molaei, E Khoddami, M Mahmoudi (2011) Active-passive immunization effectiveness against hepatitis b virus in children born to hbsag positive mothers in amol, north of iran. Oman Med $\mathrm{J}$ 26: 399-403.

15. Wang YL, Wu C Tian, Y Zhang (2017) PD-1-PD-L1 immune-checkpoint blockade in malignant lymphomas. Ann Hematol.

16. Xu-Monette ZY, J Zhou, KH Young (2017) PD-1 expression and clinical PD-1 blockade in B-cell lymphomas. Blood.

17. Zasada M, M Lenart, M Rutkowska-Zapala, M Stec, W Durlak, et al. (2017) Analysis of PD-1 expression in the monocyte subsets from non-septic and septic preterm neonates. PLoS One 12: e0186819.

18. Galmozzi EF, Facchetti G, Grossi A, Loglio M, Colombo, et al. (2017) THU-166 - Genetic variations in PD-1 and STAT4 genes do not predict off-treatment functional cure in IFN treated genotype $\mathrm{D}, \mathrm{HBeAg}$-negative patients with chronic hepatitis B. Journal of Hepatology 66: S261.

19. Zhang G, Z Liu, S Duan, Q Han, Z Li, et al. (2010) Association of polymorphisms of programmed cell death-1 gene with chronic hepatitis B virus infection. Hum Immunol 71: 1209-1213.

20. Doosti A, S Amini-Bavil-Olyaee, E Tajbakhsh, A Adeli, F Mahboudi (2009) Prevalence of viral hepatitis and molecular analysis of HBV among voluntary blood donors in west Iran. New Microbiol 32.

21. Foroughi M, S Moayedi-Nia, A Shoghli, S Bayanolhagh, A Sedaghat, et al. (2017) Prevalence of HIV, HBV and HCV among street and labour children in Tehran, Iran. Sex Transm Infect 93: 421-423.

22. Ghabeshi S, R Baktashi, SM Hosseini, Z Sharifi (2014) Molecular evaluation of HBV core gene mutations in asymptomatic HBV infected blood donors in Iran. Arch Iran Med 17: 759-762.

23. Keramat F, P Eini, MM Majzoobi (2011) Seroprevalence of HIV, HBV and HCV in Persons Referred to Hamadan Behavioral Counseling Center, West of Iran. Iran Red Crescent Med J 13: 42-46.

24. Shih CA, WC Chen, HC Yu, JS Cheng, KH Lai, et al. (2015) Risk of severe acute exacerbation of chronic hbv infection cancer patients who underwent chemotherapy and did not receive anti-viral prophylaxis. PLoS One 10: e0132426.

25. Liu X, L He, J Han, L Wang, M Li, et al. (2017) Association of neutrophil-lymphocyte ratio and $\mathrm{T}$ lymphocytes with the pathogenesis and progression of HBV-associated primary 
liver cancer. PLoS One 12: e0170605.

26. Peters S, KM Kerr, R Stahel (2017) PD-1 blockade in advanced NSCLC: A focus on pembrolizumab. Cancer Treat Rev 62: 39-49.

27. Qorraj M, M Bottcher, D Mougiakakos (2017) PD-L1/PD-1: New kid on the "immune metabolic" block. Oncotarget 8: 73364-73365.

28. Raziorrouh B, M Heeg, P Kurktschiev, W Schraut, R Zachoval, et al. (2014) Inhibitory phenotype of HBV-specific CD4+ T-cells is characterized by high PD-1 expression but absent coregulation of multiple inhibitory molecules. PLoS One 9: e105703.

29. ren Ht, Ym Li, Xj Wang, Hf Kang, Tb Jin, et al. (2016) pd-1 rs2227982 polymorphism is associated with the decreased risk of breast cancer in northwest chinese women: A hospital-based observational study. medicine (baltimore) 95: e3760.

30. Teng F, X Meng, L Kong, J Yu (2017) Progress and challenges of predictive biomarkers of anti PD-1/PD-L1 immunotherapy: A systematic review. Cancer Lett.

31. Wu Y, M Yu, Z Sun, W Hou, Y Wang, et al. (2017) Generation and characterization of a bispecific antibody targeting both PD-1 and c-MET. Protein Pept Lett.

32. Zhou JY, DF Zhou, JQ Li (2013) PD-1 expression in HBcAg-specific CD8+ T cells of adolescents with chronic HBV infection. Zhonghua Gan Zang Bing Za Zhi 21: 27-32.

33. Ulger Y, S Bayram, MU Sandıkc, E Akgollu, A Bekar (2015) Relationship between programmed cell death-1 polymorphisms and clearance of hepatitis $B$ virus. International Journal of Immunogenetics 42: 133-139.

34. Cho Hyosun, Hyojeung Kang, Hwan Lee, Chang Kim (2017) Programmed cell death 1 (PD-1) and cytotoxic $t$ lymphocyte-associated antigen 4 (CTLA-4) in Viral Hepatitis.
International Journal of Molecular Sciences 18: 1517.

35. Naghoosi, Hamed, Seyed Reza Mohebbi, Seyed Mohammad Ebrahim Tahaei, Pedram Azimzadeh, et al. (2012) Lack of the association between single nucleotide polymorphism in programmed cell death 1 gene and susceptibility to chronic hepatitis B infection in the Iranian population. koomesh Journal 14: 91-96.

36. Peng GP, W Sun, Z Sun (2007) PD-1 expression in peripheral $T$ cells of patients with $\mathrm{HBV}$ infection and its significance. Zhejiang Da Xue Xue Bao Yi Xue Ban 36: 553-560.

37. Schott DS, M Pizon, U Pachmann, K Pachmann (2017) Sensitive detection of PD-L1 expression on circulating epithelial tumor cells (CETCs) could be a potential biomarker to select patients for treatment with PD-1/PD-L1 inhibitors in early and metastatic solid tumors. Oncotarget 8: 72755-72772.

38. Skalniak L, KM Zak, K Guzik, K Magiera, B Musielak, et al. (2017) Small-molecule inhibitors of PD-1/PD-L1 immune checkpoint alleviate the PD-L1-induced exhaustion of T-cells. Oncotarget 8: 72167-72181.

39. Huo H, S Ren, S Wang, Y Xu, L Ma, et al. (2014) Ratio analysis of HBV-related liver disease and primary liver carcinoma development over 10 years in patients who received no antiviral therapy versus those treated with antiviral therapy. Zhonghua Gan Zang Bing Za Zhi 22: 68-70.

40. Li D, R Chen, YW Wang, AJ Fornace, Li HH, et al. (2017) Prior irradiation results in elevated programmed cell death protein 1 (PD-1) in T Cells. Int J Radiat Biol 1-18.

41. Ludin A, LI Zon ( 2017) Cancer immunotherapy: The dark side of PD-1 receptor inhibition. Nature. 